\title{
Corporate Sovereign Awakening and the Making of Modern State Sovereignty: New Archival Evidence from the English East India Company
}

\author{
Swati Srivastava 10
}

\begin{abstract}
The English East India Company's “company-state” lasted 274 yearslonger than most states. This research note uses new archival evidence to study the Company as a catalyst in the development of modern state sovereignty. Drawing on the records of 16,740 managerial and shareholder meetings between 1678 and 1795 , I find that as the Company grew through wars, its claim to sovereign authority shifted from a privilege delegated by Crown and Parliament to a self-possessed right. This "sovereign awakening" sparked a reckoning within the English state, which had thus far tolerated ambiguity in Company sovereignty based on the early modern shared international understanding of divisible, nonhierarchical layered sovereignty. But self-possessed nonstate sovereignty claimed from the core of the state became too much. State actors responded by anchoring sovereign authority along more hierarchical, indivisible foundations espoused by theorists centuries earlier. The new research makes two contributions. First, it introduces the conceptual dynamic of "war awakens sovereigns" (beyond making states) by entangling entities in peacemaking to defend sovereign claims. Second, it extends arguments about the European switch from layered sovereignty to hierarchical statist forms by situating the Company's sovereign evolution in this transformation. Ultimately, this study enables fuller historicization of both nonstate authority and the social construction of sovereignty in international politics.
\end{abstract}

Modern sovereignty was born in an age of empire. —Nicholas Dirks, The Scandal of Empire (2008), 203

The current international system may be exclusively composed of sovereign states, but that does not mean it was built by them. —Andrew Phillips and Jason Sharman, Outsourcing Empire (2020), 16

By 1800, the English East India Company ("the Company" or EIC) ruled one-fifth of the world using a larger military force than England's. ${ }^{1}$ It established forts and trading

1. Chaudhuri 1978; Lawson 1993.

International Organization 76, Summer 2022, pp. 690-712

(C) The Author(s), 2022. Published by Cambridge University Press on behalf of The IO Foundation. This is an Open Access article, distributed under the terms of the Creative Commons Attribution licence (https:// creativecommons.org/licenses/by/4.0/), which permits unrestricted re-use, distribution, and reproduction in any medium, provided the original work is properly cited.

doi:10.1017/S002081832200008X 
posts, organized land and naval forces, minted currency, collected taxes, and administered justice, all through a trade in spices, textiles, and opium. After the EIC's creation in 1600, English market share of Asian trade ballooned to a quarter in 1650, a third in 1780, and two-thirds in $1820 .^{2}$ The Company pilfered massive wealth from India, ${ }^{3}$ reversing capital flows from the West to the East and making possible the Industrial Revolution. ${ }^{4}$ In 1788 , philosopher and parliamentarian Edmund Burke called the Company "a state in the disguise of a merchant." 5 Recent studies examine the EIC as a "company-state," "possessed of political institutions and underscored by coherent principles about the nature of obligations of subjects and rulers, good government, political economy, jurisdiction, authority, and sovereignty." 6

In this research note I use new archival evidence to study the EIC as a catalyst in the development of modern state sovereignty, which had been faintly realized since its supposed articulation in $1648 .^{7}$ In the early modern period, one-way travel between Europe and Asia took about five months. European rulers delegated sovereign prerogatives to corporations "to pursue long-distance commerce and conquest without direct government finance or control." 8 But did company-states think of themselves as sovereign in their own right? If so, what implications did this have for states? International relations scholarship has examined the relationship of corporate power and state sovereignty, especially after the Cold War. ${ }^{9}$ Company-states present an opportunity to observe the co-evolution of corporate and state authority during an earlier period of post-Westphalian international history. The research focuses on the EIC as it began with more arms-length state relations than its main counterpart, the Dutch Vereenigde Oost-Indische Compagnie (VOC). ${ }^{10}$ After 1600, the EIC incorporated (1657), merged with a rival (1709), conquered Bengal (1757), began taxing 10 million Bengalis-twice England's population (1765), ${ }^{11}$ entered a financial crisis (1770), was bailed out by Parliament with increased oversight $(1773,1784)$, ceased to trade and became a territorial administrator (1833), relinquished India's administration to the British government (1858), and was dissolved (1874). The period between incorporation in the late 1600s and regulatory scrutiny in the late 1700s is pivotal for both the EIC's emergence as a companystate and the delegitimization of nonstate actors from the international system. ${ }^{12}$

2. Bogart 2017, 5 .

3. Dalrymple 2019,1 .

4. Erikson 2014, 32-34, 173.

5. Burke 1909, 21.

6. Stern 2008, 257. Erikson 2014; Phillips and Sharman 2015, 2020; Stern 2011; Wagner 2018.

7. Krasner 1993; Osiander 2001.

8. Phillips and Sharman 2020, 203.

9. Avant 2005; Cutler, Haufler, and Porter 1999; Fuchs 2007; Hall and Biersteker 2002; Mikler 2018; Srivastava 2021; Strange 1996.

10. Erikson 2014, 76; Sharman 2019, 178. On the VOC, see Blachford 2020; Weststeijn 2014.

11. Phillips and Sharman 2015, 173.

12. Spruyt 1994; Thomson 1994. 
Company directors met thrice a week to run the organization, and shareholders held quarterly meetings. This research draws on records of all 16,740 EIC managerial and shareholder meetings between 1678 and 1795. This unprecedented data collection was made possible by materials recently being allowed to be photographed in the British Library. ${ }^{13}$

Sovereignty is a highly contested and ambiguous "sponge-concept." ${ }^{14}$ International relations scholars are not unified in how or where they locate sovereignty, ${ }^{15}$ variously proposing that one cannot meaningfully speak of sovereignty before the sixteenth ${ }^{16}$ or the nineteenth century. ${ }^{17}$ Jens Bartelson writes that "we should avoid the direct question of what sovereignty is, and instead ask how it has been spoken of and known throughout a period of time." ${ }^{18}$ For Bartelson, one expression of sovereignty in international political thought is "self-presence and self-sufficiency; that which is sovereign is immediately given to itself, conscious of itself and thus acting for itself." 19 An inductive analysis of EIC records reveals that the Company's self-presence and self-sufficiency appeared primarily through the language of "rights." ${ }^{20}$ This conceptualization of early sovereignty fits the emergent juridical view at the time, in which "sovereignty had to be concretely legal, not simply theoretically political." ${ }^{21}$ For instance, in 1625 , Dutch theorist Hugo Grotius understood legal rights "to define the parameters within which political relationships were to be conducted, setting the boundaries of autonomy, obligation and justifiable violence."22

Using a rights-based conceptualization, analyzing Company sovereignty shows a key transformation that recovers a part of the history of state sovereignty. While at its founding Company sovereignty was delegated by royal charter (later renewed by Parliament), after the conquest of Bengal the Company's sovereign claims shifted to a self-possessed right. Following the conventional notion that "war makes states," 23 Company wars expanded territory whose revenues were better extracted by increased bureaucratic capacity. But the data also reveal a related conceptual dynamic of "war awakens sovereigns," where entities engaged in peace negotiations are stimulated by their defense of sovereign claims to conceive new self-understandings of sovereign authority. Sovereignty's emergence out of peace negotiations is well established in international relations, most commonly in the Peace of Westphalia myth, ${ }^{24}$ but also in the English School's understanding of

13. The online supplement provides an extended discussion of data and methods.

14. Bartelson 1995, 237; de Carvalho 2021. While sovereignty is the focus here, "the state" remains another related contested concept.

15. Costa Lopez et al. 2018, 493.

16. de Carvalho 2021, 503.

17. Bartelson 1995, 512.

18. Ibid., 4.

19. Ibid., 28.

20. Discussed further in the online supplement, section B.

21. Wood 1998, 346.

22. Keene 2002, 43.

23. Tilly 1985.

24. Krasner 1993. 
treaties socializing states ${ }^{25}$ and sovereign grants as "spoils of war." 26 In the EIC's company-state, wars generated continuous articulations of Company sovereignty vis-à-vis Asian powers and European rivals. Dividing tax revenues after conquest further entangled the Company's sovereign claims with the English state. Over time, these contests led to a notion of self-possessed Company sovereignty, complicating the standard narrative of the EIC as "accidental and unwilling" sovereigns. ${ }^{27}$

The Company's sovereign awakening redefines the EIC's challenge to the English state. Existing scholarship on EIC-state relations posits that Company misrule led to more demarcations of public and private, such that by the 1800s company-states were no longer "indispensable substitutes for sovereign state power." 28 The research here shows that it was not just mismanagement but also self-possessed Company sovereignty that sparked a state reckoning. Importantly, the sovereign awakening was not limited to Company officials in India ${ }^{29}$ but extended to the London directors. Until the late 1700s, the English state had tolerated ambiguity in Company sovereignty based on the shared international understanding of divisible, nonhierarchical layered sovereignty. ${ }^{30}$ But self-possessed nonstate sovereignty claimed from the core of the state became too much. State actors responded by anchoring sovereignty along more indivisible, hierarchical foundations espoused by theorists centuries earlier.

This note contributes to the study of international politics by folding companystates into accounts of the social construction of sovereignty ${ }^{31}$ in two ways. First, constructivists have long argued that "the sovereign state is an ongoing accomplishment of practice, not a once-and-for-all creation of norms that somehow exist apart from practice." 32 Moreover, "rather than proceeding from the assumption that all states are sovereign, [they] are interested in considering the variety of ways in which states are constantly negotiating their sovereignty." 33 Studying the EIC sheds light on these negotiations by illustrating how the Company's self-possessed sovereignty was constructed in moments of contestation with other sovereigns. The recent practice turn also emphasizes that "sovereignty is produced and reproduced (and transformed) through changing diplomatic practices." 34 Along these lines, as the Company's affairs increasingly consisted of navigating complex political alliances in India and England, diplomatic entanglements awakened the Company to notions of sovereignty enduring beyond delegated privilege.

25. Watson 1992.

26. Keene 2002, 47.

27. Bayly 1988, 2-3; Bowen 1991, 5.

28. Dirks 2008, 197; Phillips and Sharman 2020, 111.

29. Stern 2008, 254.

30. Benton 2009, 148.

31. Biersteker and Weber 1996; see Glanville 2013 for a recent overview.

32. Wendt 1992, 413.

33. Biersteker and Weber 1996, 11.

34. Sending, Pouliot, and Neumann 2015, 17. 
Second, the note situates the EIC's sovereign evolution within the modern European transformation ${ }^{35}$ out of nonhierarchical layered sovereignty. Studies of early sovereignty have debunked Westphalia producing sovereign equality in 1648 and shown that the sovereign state's institutional victory was not inevitable. ${ }^{36}$ By the 1800 s, states gradually disavowed delegating sovereign violence to nonstate actors to institutionalize nonintervention norms for other states. ${ }^{37}$ The history of the EIC further shows that states also confronted company-states as sovereign rivals and wrestled with nonstate sovereignty, which extends the recent centering of colonial encounters in historicizing the international system. ${ }^{38}$ Moreover, contests between Company and Parliament over the proper locus of sovereign authority highlight Richard Ashley's observation that sovereignty's “empirical contents are not fixed but evolve in a way reflecting the active practical consensus among coreflective statesmen who are ever struggling." 39 The English loss of the American colonies is recognized as setting a new practical consensus of sovereignty; ${ }^{40}$ the EIC's self-understanding as "statesmen" should be regarded as equally important.

Moving forward, the second section overviews early modern layered sovereignty and contextualizes the Company's delegated authority. The third section describes the development of the EIC's company-state from the late 1600s. The fourth section traces the EIC's sovereign awakening from the mid-1700s as it claimed Company sovereignty as a self-possessed right. The fifth section follows the English state's reckoning with the corporate sovereign awakening in the late 1700s.

\section{Early Modern Layered Sovereignty}

Between 1500 and 1800, "composite forms of state, empire, and sovereignty were central to the constitution of political power." 41 The Indian Ocean reflected a "shared and layered concept of sovereignty" 42 in the delegation of sovereign functions to a variety of actors, such as "ship captains, leaders of reconnaissance voyages, trading companies, municipalities, colonial governors or viceroys, and garrison commanders." 43 European empires were propelled by such "divisible prerogatives." 44 War and commerce were conducted in "a world in which national territorial states did not have a monopoly on political power and in which sovereignty

35. Phillips and Sharman 2015; Ruggie 1993; Spruyt 1994.

36. Osiander 2001; Spruyt 1994.

37. Thomson 1994.

38. Branch 2012; Phillips and Sharman 2020.

39. Ashley 1984, 272, n101.

40. Benton 2009; Dalrymple 2019; Dirks 2008; Wood 1998.

41. Stern 2008, 260.

42. Bose 2006, 25.

43. Benton 2009, 31.

44. Phillips and Sharman 2020, 22. 
was composite, incomplete, hybrid, layered, and overlapping." 45 The resulting orders were "multicentric." 46 Mutually inclusive delegated authority from state sovereigns to others was not obviously hierarchical, such that states would retain "ultimate authority" (variously defined). ${ }^{47}$ Instead, early modern sovereignty was "widely understood as a work in progress." 48

Meanwhile, legal theorists conceived of sovereignty as indivisible as early as 1576 , when Jean Bodin wrote, "The prerogatives of sovereignty have to be of such a sort that they apply only to a sovereign prince. If, on the contrary, they can be shared with subjects, one cannot say that they are marks of sovereignty ... By logical necessity two infinities cannot exist." ${ }^{49}$ Less than a century later, Thomas Hobbes presented sovereignty as "indivisible, unlimited and illimitable." ${ }^{50}$ However, Bodin and Hobbes "served not to describe political reality but to prescribe a remedy for the chaos they saw as arising from the complex and unsettled relationship" among competing authorities. ${ }^{51}$ The indivisibility doctrine "conflicted with the realities of composite polities, jurisdictional tensions, and intrastate violence." 52 The mismatch is evident in Grotius, also a VOC lawyer, who both conceived of "sovereignty as a unity, in itself indivisible" and acknowledged sovereign divisibility: "It may happen that a people, when choosing a king, may reserve to itself certain powers but may confer others on the king absolutely." 53

Within this context, the EIC's founding charter formalized the royal delegation of sovereign powers. The Company had liberty to "make laws and impose penalties on offenders," as long as they were not "repugnant to the Laws of England." 54 It could grant a trade license "to or from the East-Indies." 55 While the Company could wage war using the Crown's ships since $1600,{ }^{56}$ in 1661 it could raise its own military forces ("send out ships of war, men or ammunition for security and defense") and choose its commanders and officers, and had the "power and authority to continue or make peace" with non-Christians. ${ }^{57}$ In 1669 , the Company was granted control over Bombay (which had been gifted to Charles II by the Portuguese in his dowry), which was the first mention of sovereignty in the charters: "Cede Bombay together with all the Rights, Profits, Territories and Appurtenances thereof, and as well the Property as the direct, full and absolute Dominion, and Sovereignty of the

45. Stern 2008, 257.

46. Benton 2009, 32, n89.

47. Costa Lopez 2020, 226-30.

48. Benton 2009, 38.

49. Bodin 1992, 49-50.

50. Hobbes 1994, 81.

51. Stern 2008, 259.

52. Benton 2009, 280.

53. Keene 2002, 44.

54. IOR-A/2/3, 13-14. IOR refers to India Office Records throughout.

55. Ibid., 21.

56. Ibid., 20.

57. Ibid., 76, 75. 
said Port and Island." 58 As of 1677 , the Company could mint its own money. ${ }^{59}$ As expected in layered sovereignty, the charter's sovereign grants "could not simply be revoked by either the crown or parliament, nor did they carry responsibilities of service to either institution." 60 The Company instead exuded "a dual personality: subject to the English Crown in one sense but possessed of a supreme rule abroad in another: "wee act by his authority, so their dependence is on us, and they act by ours." ${ }_{61}$

Early modern layered sovereignty thus promoted nonhierarchical delegation of sovereign authority. The persistence of layered sovereignty into the early 1800 s complicates linear narratives of hierarchical state formation and indivisible sovereignty in post-Westphalian Europe. ${ }^{62}$ But by the late 1700 s, it became evident that imperial expansions "opened spaces for a host of other rival political communities that also engaged in the business of empire." ${ }^{63}$ The jurisdictional issues of layered sovereignty "could be left vague until they collided with the anxieties that grew around the expansionist activities of [sovereign rivals like] the East India Company." 64 A 1772 tract by English MP William Bolts claimed

there is something excessively ridiculous in the very idea of vesting a body of mere traders with unlimited sovereign authority, and setting them between the real Sovereign and people of this kingdom, and two mock Sovereigns and the whole people of the Bengal provinces, to play securely their own game of advantage, to the prejudice of all the other parties. ${ }^{65}$

Over the ensuing decades, the international system shifted from one permissive of layered sovereignty to "an ever more restrictive one in which prerogatives of government were presumed to lie exclusively with sovereign states."66 The EIC's sovereign awakening had a role to play in this transformation. But first, the Company assumed a more state-like form in India.

\section{Emergence of a Company-State}

The EIC had ambitions for establishing its own state from the late 1600s. In 1674, the directors thought Bombay could be "'settled in the way of a colony'; a decade later, it was announced to be the 'principal seat of our trade as well as of our power,' the base

58. Ibid., 82.

59. Ibid., 111.

60. Stern 2011, 23-25.

61. Ibid., 26 (quoting EIC directors, 16 February 1669).

62. Krasner 1993; Spruyt 1994; Tilly 1990.

63. Stern 2008, 259.

64. Dirks 2008, 206.

65. Bolts 1772, 219-20.

66. Phillips and Sharman 2020, 212. 
of operations for the Company's head of its affairs in Asia." ${ }^{67}$ In 1682, they asserted: "If profit was the prime end of commerce, revenue was the ultimate goal of politics: the lifeblood of a polity, 'essential to all Governments in ye World."'68 The same year, the Company brought a high-profile lawsuit against an interloper (unlicensed trader), Thomas Sandys. Interlopers were a major problem for the Company because "they trespassed on its jurisdiction and resisted and flouted its authority as a government." 69 The Company had Sandys's ship stopped by the Admiralty on the Thames and brought him to the Court of Chancery. ${ }^{70}$ Sandys "challenged the Admiralty's right to seize his ship, arguing that its civil law jurisdiction extended only to the high seas ... He made no effort to deny he planned an eastward voyage. He insisted instead that, according to common law, he had every right to do so, since the Company's charter, being for a monopoly, was 'in it self void." 71

During the East India Company v. Sandys trial (1683-84), the Company took credit for its sovereign powers: "In the East Indies, it was the Company, not the English crown, that maintained the physical infrastructure of commerce, such as forts and forces, as well as the political infrastructure, most notably through diplomacy, which made trade and the very intercourse with Asia possible." 72 The defense retorted that "vesting in the Company such responsibilities and autonomy altered the very constitution of England and rendered the Company no less than 'a sort of republic for the management of trade." "73 The case was decided in favor of the Company. But the verdict defended the Crown's authority as the source of Company sovereignty: "The King hath the sole power of this trade, as of war and peace; and by declaring a war, he may determine a public trade, though settled by the act of parliament." 74 Perceptively, the decision concluded by citing Grotius: "The company hath been in possession of this trade near one hundred years, and that possession will in time give a right." 75

Two years later, Company directors regarded the Crown and Parliament's sovereignty as extending "no farther than 'the Kingdoms of England, the Dominion of Wales, and the Town of Barwick upon Tweed." "76 In 1689, the directors wrote to the Bombay Council that increasing revenues "is no less the subject of our [concern] \& must always be yours, as much as our trade; 'tis that must make us a nation in India, without that we are but as a great number of Interlopers, united by his Majesties Royall Charter, fit onely to trade where no body of power thinks it

67. Stern 2008, 275.

68. Ibid., 280.

69. Stern 2008,268 .

70. Howell and Howell 1816, 385.

71. Stern 2011, 46.

72. Stern 2008, 270.

73. Ibid., 271-72.

74. Howell and Howell 1816, 517.

75. Ibid., 520.

76. Stern 2008, 279. 
their interest to prevent us." ${ }^{\text {"77 }}$ In 1691, the directors invoked the VOC as a model "to create a self-sustaining political and military establishment in India founded upon the raising of local revenue, of the sort that 'enables [the Dutch] to secure ... their soveraigne state in India." 78 Unlike the Dutch, the EIC intended its self-sustaining state to be free of delegation. But at this time, the Company could not consider freeing itself from the Mughal farman (authorization). ${ }^{79}$ The Company displayed formal deference to the Mughals from its beginning. ${ }^{80}$ Directors also "used Mughal grants to evade English authority. Company [directors] were insistent, for example, that their subordinates take their 'phyrmaund or agreement in the name of the English East India Company only, \& not the English Nacon in general,' so as to reconfirm that it was the Company's government, not the English government, that had jurisdiction in Asia." 1

The Company's desire for a state would be fulfilled in Bengal, not Bombay. By 1690, the Company set up a trading post and established Fort William in Calcutta. In 1717, it negotiated a trade license with Mughal Emperor Farrukhsiyar. A decade later, Bengal's exports made up 70 percent of the Company's trade. The Company conflicted with the nawab of Bengal in a series of escalations, including dismissing its entire Bengal Council in 1732. The crisis came to a head under a different nawab, Siraj ud-Daulah, who attacked Fort William in 1756 with the French, resulting in a siege of Calcutta. By January 1757, the Company, led by Robert Clive, recaptured Calcutta, and then in June won Bengal in the Battle of Plassey. Clive was appointed Bengal's president and governor in 1759, returning to a second term in 1765. Plassey led to big military and financial gains ( $£ 232$ million today), allowing the Company to wrest control over the right to tax collection (diwani) from the Mughals in 1765. A century after Westphalia, the EIC became the "de facto territorial sovereign of Bengal." ${ }^{2}$ Along with this came a transformation in Company sovereignty.

\section{Company Sovereignty as Self-Possessed Right}

The EIC's sovereign awakening consisted of claiming Company sovereignty as a self-possessed right rather than a delegated privilege. The sovereign awakening emerged from the Company's experiences in Bengal, which was acquired by conquest rather than by grant like Bombay. In 1765, Clive argued:

Princes of Indostan must conclude our Views to be boundless ... We must indeed become the Nabobs ourselves in Fact, if not in Name, perhaps totally

77. Ibid.

78. Ibid., 280.

79. Stern 2008, 267.

80. Phillips and Sharman 2015, 149-59.

81. Stern 2008, 266.

82. Erikson 2014, 65. 
without Disguise ... Let us, and without delay, compleat our three European Regiments to one thousand each ... If Riches and Stability are the Objects of the Company, this is the Method, the only Method we now have for attaining and securing them. ${ }^{83}$

Clive invoked war as the source of Company sovereignty. The Company had already warred for more than a century. Yet, after 1750, "the dissolution of the Mughal Empire, the emergence of post-Mughal successor kingdoms, and Anglo-French global warfare created a volatile context in which British and EIC forces in South Asia became entangled in indigenous political and military affairs." ${ }^{44}$ After the grant of diwani, the Company fought the Mysoreans (1767-69, 1780-84, 1789-92, 1798-99), Rohillas (1773-74, 1794), French (1778-83), and Marathas (1775-82). While previous wars were fought for commercial rights and ports, Bengal gave the Company a source of territorial revenues and helped make a state better suited to extraction..$^{85}$

War also awakened a sovereign by entangling the Company in peace negotiations that forced it to articulate Company sovereignty vis-à-vis Indian powers and European rivals. During the EIC's Second Carnatic War (1749-54) with the French East India Company, the two companies secretly negotiated a peace agreement dividing territory, recognizing other sovereigns, and exchanging prisoners of war and deserters. ${ }^{86}$ The same pattern played out as the Company negotiated with the VOC in Bengal, ${ }^{87}$ agreeing in 1763 that the Dutch-preferred Mir Jafar would be restored as nawab while the EIC maintained functional control. ${ }^{88}$ Clive told the directors that Mir Jafar would be a fig leaf for Company sovereignty, though "all revenues will belong to the Company," to avoid "umbrage" and loss of revenue from Europeans who might refuse to acknowledge the Company as the sole "Nawab of Bengal." ${ }^{89}$ By 1769, Clive removed the fig leaf and declared in Parliament:

The East India Company are at this time sovereigns of a rich, populous, fruitful country in extent beyond France and Spain united; they are in possession of the labour, industry, and manufactures of twenty million of subjects; they are in actual receipt of between five and six millions a year. They have an army of fifty thousand men. ${ }^{90}$

Importantly, Clive did not link Company sovereignty to any delegation; the claim stood on the EIC's own sovereign agency.

84. Vaughn 2019, 5.

85. Tilly 1985 .

86. IOR-B.72, 493-94.

87. IOR-B.78, 47.

88. Ibid., 134.

89. IOR-E.4.27, 32-33.

90. Dirks 2008, 177-78. 
Company directors adopted Clive's declaration of self-possessed sovereignty. Figure 1 plots the number of discussions of Company sovereignty in director meetings between 1750 and 1775.91 The inductive analysis does not rely solely on mentions of "sovereign" or "sovereignty," since these terms were not well established. Instead, directors often invoked "rights" broadly to make claims about Company sovereignty. The distribution shows spikes related to peace agreements with the French (1753, 1765), the VOC (1761), and the Levant Company (1764-65). The diwani led to more sovereignty talk (1765-67), and a 1773 regulatory act yielded the most discussion.

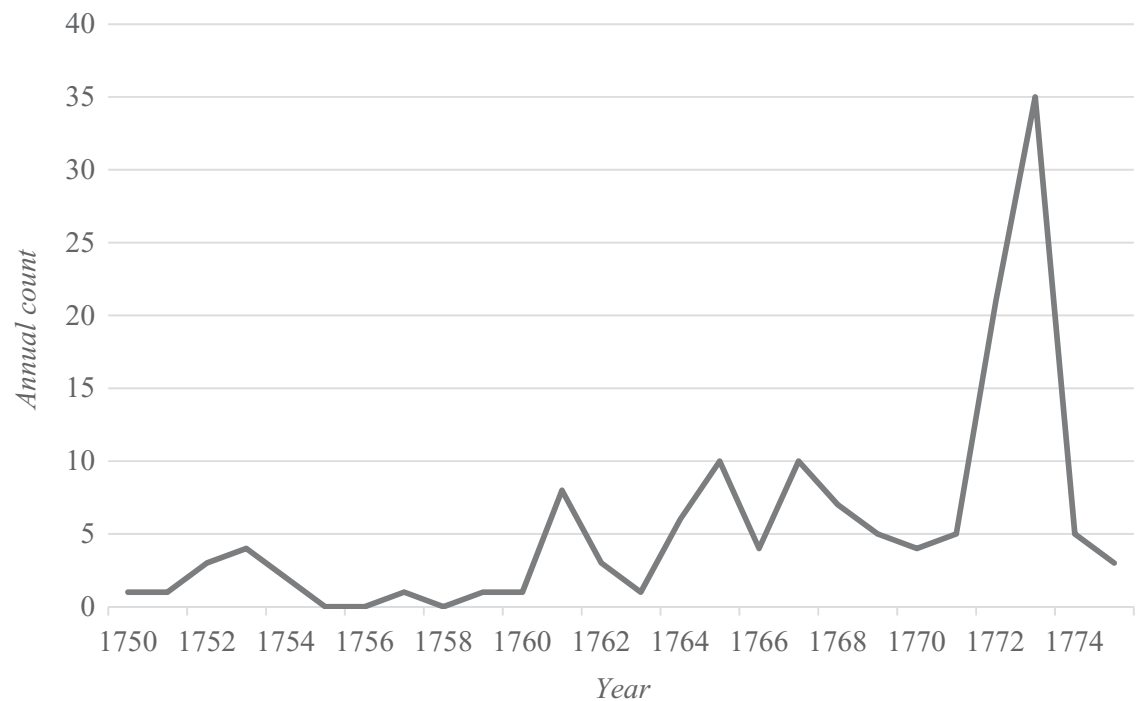

FIGURE 1. Discussion of sovereign rights in East India Company director meetings, by year, 1750-1775

The Company's war making reverberated in England. Both Crown and Company troops fought the French during the Third Carnatic War (1756-63). In 1757, when determining how to divide the spoils of wars, "the Crown's advocate, attorney, and solicitor generals implied that, legally speaking, there were in fact two wars going on simultaneously." 92 In 1769, after the Company assumed the diwani, the Crown asked that the commander of a royal ship to India contracted by the Company get a vote at the Indian governing councils. The request centered on "the powers it may be proper for the company to give the crown." 93 While the EIC was established

91. "Discussion" is operationalized as Company sovereignty featuring as an agenda item. Section B in the online supplement provides additional details.

92. Stern 2011, 197.

93. IOR-B.85, 171. 
by royal charter so it could borrow sovereign authority to legitimize its monopoly and powers, now Company sovereignty was necessary to legitimate the Crown's sovereign powers in India. Such mutually inclusive delegated relations were permissible in layered sovereignty. After debating, the directors ruled out a Crown vote on Company war- and peacemaking, but granted the Crown's officer "a share in the deliberations and resolutions of the Company merely with regard to the two objects of making peace and declaring war when his majesty's forces are employed."94

In 1767 , the directors separated trade profits, subject to public payment through dividends, from the diwani's territorial revenues, which they claimed the public or government was not entitled to share. ${ }^{95}$ A parliamentary inquiry ensued. A select committee argued that "the armies [the Company] maintained, the alliances they formed and the revenues they possessed procured them consideration as a sovereign and politic, as well as a commercial body." 96 But MP Lord Chatham claimed "that the legal right to the Company's recently acquired territories and rights in Bengal lay with the Crown rather than the Company." 97 Another committee inquired into who could lay claim to Bengal given it was the Mughals, not the Crown, that granted the diwani. Burke, a Company supporter at the time, "was concerned that the ministry was attempting to infringe on the Company's basic chartered privileges." 98 The inquiry revealed the EIC was "deliberately ambiguous on the question of sovereignty." $"$ The Company agreed to pay $£ 400,000$ ( $£ 46$ million today) annually to Parliament in lieu of a claim on diwani right or revenue. ${ }^{100}$ But within three years the Company became unable to pay this after entering a financial crisis due to corruption, wars, and losing its tea trade in America to Dutch smuggling. Parliament resolved for stricter oversight and launched an investigation into Clive's wealth. An anonymous tract argued that "only the king was the 'supreme Arbiter, by the British constitution, of all matters of war and peace."'101 MP John Burgoyne's motion that "all territorial acquisitions made by subjects belonged to the Crown" passed by a wide margin. ${ }^{102}$ But layered sovereignty was not unraveled so easily.

In 1772, Prime Minister North audited the Company and proposed a bill to appoint a governor-general in India in exchange for a $£ 1.5$ million bailout. The Company had borrowed from the government before without oversight. The directors petitioned against "the intention of Parliament to infringe those sacred rights which the East India Company have hitherto enjoyed and exercised with the greatest and most extensive advantages to the commerce and revenue of this kingdom." 103 When the

94. IOR-B.85, 212.

95. Ibid., 430.

96. Bowen 1991, 9-10.

97. Dirks 2008, 178-79.

98. Ibid., 179.

99. Ibid.

100. Dirks 2008, 179-80.

101. Phillips and Sharman 2020, 145.

102. Dirks 2008, 181.

103. IOR-B.258, 81-82. 
directors petitioned Parliament in 1698 against a rival company, they claimed it would infringe on the EIC's "rights, privileges, and inheritances." 104 Now, the Company jettisoned "privileges and inheritances" and stuck with "rights" exclusively. The directors were most aggressive when defending appointing personnel in India as "their undoubted legal right." 105 Retaining control over appointments was important because two-way correspondence between India and England took ten months. In that span of time, major wars could be initiated and peace terms concluded. The directors had to ensure they had final say in who would act discretionally on their behalf. The Company's sovereignty claim was still based on the charter, but now the charter's authority itself did not rely exclusively on delegated authority from Crown or Parliament: "The Company therefore do with all humility claim the benefit of the Law of the Land, and the public faith of the Nation, for the free enjoyment and exercise of the rights and powers which they hold." 106 The EIC thus fulfilled the prediction made in the Sandys verdict, almost a century earlier, of being entitled to certain rights from a long-held monopoly.

Parliament passed a follow-up resolution in 1773, asserting that the Company's territory, military, treaty commitments to foreign princes, money and property, and most of all its "military and civil powers" "of right belong to the State."107 The Company responded that it would rather refuse the bailout than agree to the terms. ${ }^{108}$ The directors claimed Company sovereignty as "nothing less than the preservation of their essential rights" 109 and framed their fight as being against abuse of "powers of the State." 110 The Company's sticking point remained the appointment of officers, arguing it would be nonsensical for appointees of Parliament or Crown to "be vested with the whole civil and military authority of the Presidency of Bengal, Bihar, and Orissa." 111 The directors asserted that the bill "under the colour of regulation will annihilate at once the powers of the East India Company and virtually transfer them to the Crown." 112

The Company leveraged its parliamentary connections, ${ }^{113}$ and North ultimately "decided not to push the constitutional argument about who owned Bengal, and also shied away from touching the Company's monopoly, realising that this was the prime mechanism for returning Indian tribute to Britain." 114 Clive was cleared of all charges. Parliament retained Warren Hastings, former governor of Calcutta, as the governor-general, while the Company held a majority on his executive

104. IOR-B.41, 286.

105. IOR-B.258, 81-83.

106. Ibid.

107. IOR-B.89, 116.

108. IOR-B.258, 211.

109. Ibid.

110. Ibid.

111. Ibid., 242.

112. Ibid.

113. Ibid., 254.

114. Robins 2006, 107. 
council and appointed its own president and council in Bengal, Madras, and Bombay. ${ }^{115}$ A hundred and twenty-five years after Westphalia, the English state began questioning aspects of layered sovereignty while leaving its nonhierarchical spirit largely undisturbed.

\section{Corporate Empire on Trial}

The EIC's sovereign awakening continued during Hastings's tenure as governorgeneral and instigated the next iteration of co-evolving corporate authority and state sovereignty dynamics. In particular, Hastings's high-profile impeachment trial at the close of the 1700s formed the bridge to more hierarchical and exclusive conceptions of English state sovereignty in the nineteenth century. Hastings's mandate was to establish a bureaucratic structure for revenue collection. ${ }^{116}$ By the mid1770s, he had created a revenue board and two courts, but he argued "that the collection of revenue was the task of a state rather than a trading company, requiring greater executive authority and power." 117 Hastings advocated that the "sovereignty of this country [be] wholly and absolutely vested in the Company,' and that he be the sole 'instrument' of this sovereignty." 118 However, he proposed establishing this supreme sovereignty from "clearer ties with the Crown," 119 which was now at odds with the directors. Meanwhile, Hastings "began to take a more old-fashioned, pseudo-monarchical and even despotic idea of his powers." 120

In June 1782, Parliament called on the directors to remove Hastings for what it deemed unlawful imprisonment of the raja of Benaras. ${ }^{121}$ In August, the directors agreed to remove him. ${ }^{122}$ In the interim, Hastings gained ground in the first Anglo-Maratha war (1775-82), after the EIC nearly suffered defeat. In October, the directors rescinded the removal, arguing it would be improper "to remove any of those principal servants of the company now discharging their duty with such uncommon exertions, ability, and unanimity or to shake the authority reproved in them by the legislature and the company at a period so critical." 123 Thus, warmaking created political space for Hastings's continued appointment. Furthermore, the directors explicitly claimed that his authority was jointly constituted by Parliament and Company.

After learning of the initial removal, Hastings intended to resign. In a scathing March 1783 letter to the directors, he denounced their lack of financial support for

115. IOR-B.258, 323.

116. Bowen 1991, 113.

117. Ibid., 184.

118. Ibid., 187.

119. Ibid.

120. Dalrymple 2019, 312.

121. IOR-B.260, 210.

122. IOR-E.4.627, 530.

123. IOR-B.260, 219. 
Company wars. ${ }^{124}$ Hastings also discussed his sovereign authority, first noting that he "had to contend not with ordinary difficulties, but such as most unnaturally arose from the opposition of those very powers from which I primarily derived my authority, and which were required for the support of it." 125 The "powers" here can mean the directors as well as Parliament. Hastings continued:

There was indeed an interval, and that of some duration, in which my authority was wholly destroyed; but another was substituted in its place, and that, though, irregular, was armed with the public belief of an influence invisibly upholding it, which gave it a vigor scarce less effectual than that of a constitutional power. ${ }^{126}$

It can be inferred that although Parliament and directors "wholly destroyed" the "constitutional" source of Hastings's authority when calling for his removal, he "substituted" authority from another "irregular" source. While Hastings does not further specify the alternative source, the letter centers the managing of war and diplomatic entanglements by boasting of his military victories and "advantage of local knowledge." 127 This interpretation is supported by the directors' response, which commended Hastings's work "during the late hostilities in India, particularly in finding resources for supporting the war in the Carnatic under so many pressing difficulties when that country was in danger of being lost ... and also in concluding the late treaty of Peace with the Marathas." 128

When the directors refused to remove Hastings, Parliament resumed consideration of the Company's affairs. ${ }^{129}$ As a draft bill circulated in November 1783, Burke, previously a EIC supporter, now wondered: "What did it mean for the Company to 'possess' India, whether by Parliamentary right, sheer force, or local treaty?" 130 A year earlier, Burke had argued that the nation was "not an idea only of local extent, and individual momentary aggregation; but it is an idea of continuity, which extends in time as well as in numbers and in space." ${ }^{131}$ For Burke, national sovereignty

is a deliberate election of ages and generations; it is a constitution made by what is ten thousand times better than choice, it is made by the peculiar circumstances, occasions, tempers, dispositions, and moral, civil and social habitudes of the people, which disclose themselves only in a long space of time. It is a vestment which accommodates itself to the body. ${ }^{132}$

124. IOR-E.4.40, 385-86.

125. Ibid., 386.

126. IOR-E.4.40, 387.

127. Ibid., 386.

128. IOR-B.99, 546.

129. Ibid., 563.

130. Dirks 2008, 167.

131. Ibid., 193-94.

132. Ibid., 194. 
Burke's views were "changed greatly from those he had held in younger years," and "it cannot be accidental ... that Burke was spending most of his time thinking about Company abuses in India, wondering whether Warren Hastings was undermining universal principles and national reputations." 133

The directors warned Parliament that the bill would be "subversive of your petitioners constitution, divesting them of their rights and privileges, seizing their property and continuing a trade at their risk but without their consent or control." ${ }^{134}$ Later, the directors agreed to concede to some provisions as long as "the government in India be carried on in the name of the company by a Governor and three counsellors, at each of the presidencies of Madras and Bombay." 135 They queried: "Will there remain with the executive body of any decisive or conclusive authority respecting the commercial affairs of the company? Will the heads of the intended bill go to the annihilation of the company's authority in India, and will all the power and authority of the company be vested in the governors and council to be named by the crown?"136 Pitt's India Act (1784) aimed to resolve these questions with six Commissioners for the Affairs of India as an arm of Parliament to establish "dual control" over India alongside the Company, with the intent to leave "ultimate authority" in the British government. The act forbade the Company to "pursue schemes of conquest and extension of dominion in India."137

Yet, Hastings continued with self-authorized wars. ${ }^{138}$ The directors had instructed against EIC "interference in the objects of dispute between the Country Powers." 139 In June 1784, Hastings justified interfering in a conflict in Delhi because he considered the sovereign authority of imprisoned Mughal emperor Shah Alam II, who returned to the throne under protection of the Marathas, as not fitting the meaning of "'Country Powers,' to which that of permanency is a necessary adjunct; and which may be more properly compared to a splendid bubble which the slightest breath of opposition might dissipate with every trace of its former existence." 140 The directors also gave Hastings latitude in implementing the 1784 act, claiming they were unable to maintain proper oversight on which Indian offices to reduce:

We found it difficult and in many cases impossible to discover the real present value of such offices ... We have come to the conclusion of leaving the first detail of it in your hands, reserving to ourselves the final examination and approbation of the establishment made up by you."141

133. Ibid., 195.

134. IOR-B.260, 298.

135. Ibid., 309.

136. Ibid., 313.

137. Lawson 1993, 128.

138. Dirks 2008, 188

139. IOR-E.4.42, 100.

140. Ibid., 103-04.

141. IOR-E.4.629, 207-08. 
The directors relayed that while the act established guidelines for administering justice in India, they "recommend it is your particular consideration how far it may not be practicable to owe the offices you may find it necessary to keep up ... We are sensible that in the application of this principle, modifications and exceptions may become necessary." 142 Meanwhile, Hastings reminded the directors about his wish to resign, alluding to deteriorating health, ${ }^{143}$ and he was allowed to leave in February $1785 .{ }^{144}$

Following Hastings's departure and the new act, the Bengal Council protected the Company's self-possessed sovereignty. In July 1785, the council told Maratha ruler Mahadji Shinde that they

had taken pains to publish to the native powers those principles of a publick system which have been so wisely established in the last act of the British legislature, but it was proper also to be publickly understood that these were not to be perverted to any interpretation that could weaken your actual authority or reflect discredit instead of honor on your management of it. ${ }^{145}$

The statement reflects that the Company's delegated-authority contests in England rebounded in India. But EIC administrators continued to assert their "actual authority" regardless of the London machinations. The EIC's Maratha representative also conveyed that "after his remonstrance was made pubick in Sindia's durbar [court], he received visits from the vakeels [regents] of the different states of India, who attended the Shaw and Maratta camps, and offered to join the English against Sindia." 146 In this manner, the Company's reassertion of "actual" sovereign authority signaled their military credibility to the Indian powers balancing against the Marathas.

Hastings arrived in England in June 1785 and was unanimously thanked by the directors for his "long, faithful and able services." 147 Throughout the year, he corresponded with them on plans for military establishments in India. ${ }^{148}$ In February 1786, Burke launched an impeachment inquiry into Hastings ${ }^{149}$ and made numerous requests for Company records. ${ }^{150}$ That summer, the House of Commons voted to impeach Hastings. But there was no mention of the vote in the directors' minutes.

142. Ibid., 210-12.

143. IOR-E.4.42, 257.

144. IOR-B.100, 954.

145. IOR-E.4.43, 136.

146. Ibid., 136-37.

147. IOR-B.101, 178.

148. Ibid., 331, 336, 424, 644.

149. IOR-B.102, 797.

150. Ibid., 799, 800-02, 911-13, 936-37, 983, 996; IOR-B.103, 142, 147, 1066, 1073; IOR-B.104, 1038-40, 1051, 1066, 1072-73, 1095, 1103-04, 1126, 1129. 
The Company did not even retain legal counsel until the trial began almost two years later, ${ }^{151}$ nor did it petition Parliament regarding Hastings's impeachment. ${ }^{152}$

The trial began in February 1788 and lasted seven years in the House of Lords. It was the event of the season, with tickets going "for as much as $£ 50(£ 5,250$ today)." 153 The trial was "not just the greatest political spectacle in the age of George III, it was the nearest the British ever got to putting the Company's Indian Empire on trial." 154 In an impassioned opening argument, Burke identified the Company's rapaciousness as "more like an army going to pillage the people, under the pretence of commerce than anything else." ${ }^{155} \mathrm{He}$ challenged the English public to "realize that the crisis of legitimacy in India could lead to a crisis of legitimacy in Britain." $156 \mathrm{He}$ argued that the EIC

was no longer merely a mercantile company, formed for the extension of the British commerce; it more nearly resembled a delegation to the whole power and sovereignty of this kingdom, sent into the East. From that time the Company ought to be considered as a subordinate sovereign power; that is, sovereign with regard to the objects which it touched, subordinate with regard to the power from whence its great trust was derived. ${ }^{157}$

After the grant of diwani, Burke argued, the Company ceased behaving like a subordinate power. He read aloud Hastings's claims of self-possessed Company sovereignty:

The sovereignty which they assumed fell to my lot, very unexpectedly, to exert; and whether or not such power, or powers of that nature, were delegated to me by any provisions of any Act of Parliament, I confess myself too little of a lawyer to pronounce. I only know that the acceptance of the sovereignty of Benares, \&c., is not acknowledged or admitted by any Act of Parliament; and yet, by the particular interference of the majority of the council, the Company is clearly and indisputably seized of that sovereignty. If, therefore, the sovereignty of Benares, as ceded to us by the vizier, have any rights whatever annexed to it (and be not a mere empty word without meaning), those rights must be such as are held, countenanced, and established by the law, custom, and usage of the Mogul empire, and not by the provisions of any British Act of Parliament hitherto enacted. Those rights, and none other, I have been the involuntary instrument of enforcing. And if any future act of Parliament shall positively, or by implication, tend to annihilate those very rights, or their exertion, as I have exerted them, I much fear that the boasted

151. IOR-B.106, 1060.

152. Discussed more in section $\mathrm{C}$ of the online supplement.

153. Dalrymple 2019, 307.

154. Dalrymple 2019, 308.

155. Ibid., 93.

156. Dirks 2008, 190.

157. Burke 1909, 19. 
sovereignty of Benares ... will be found a burden instead of benefit, a heavy clog rather than precious gem to its present possessors. ${ }^{158}$

For Hastings, rights gave meaning to sovereignty. He referred to rights four times when declaring that Company sovereignty over conquered territories, like Bengal and Benares, was not delegated by English authority but operated within the Mughal sovereign system. Hastings also claimed that Company sovereignty was absolute, otherwise sovereignty would be as useless as a "heavy clog."

Burke countered that no legitimate government can delegate absolute sovereignty: "absolute, supreme dominion was never conferred or delegated by [Parliament]."159 He continued:

Before Mr. Hastings none ever came before his superiors to claim it; because, if any such thing could exist, he claims the very power of that sovereign who calls him to account ... Such a claim is a monster that never existed except in the wild imagination of some theorist ... No country has wholly meant, or ever meant, to give this power. ${ }^{160}$

Burke often invoked the supreme sovereignty of the Crown ("here we see virtually in the mind's eye that sacred majesty of the crown, under whose authority you sit, and whose power you exercise") and Parliament ("[Hastings] had sent even the plan of an Act of Parliament, to have it confirmed with the last and most sacred authority of this country"). ${ }^{161} \mathrm{He}$ denied that non-Europeans had a different conception of sovereignty: "The supreme power of the state in the Mogul empire did by no means delegate to any of its officers the supreme power in its fulness." Thus, "in Asia as well as in Europe, the same law of nations prevails; the same principles are continually resorted to; and the same maxims sacredly held and strenuously maintained." 162 Burke's idea of indivisible absolute sovereignty as a "law of nations" recalled Bodin's doctrine of two centuries earlier.

In 1795, Hastings was acquitted, which Burke had anticipated given the EIC's parliamentary connections and rampant corruption. ${ }^{163}$ Yet, the trial created political space to "demonstrate that the Company's many misdeeds were answerable to Parliament, and it helped publicise the corruption, violence and venality of the EIC, so setting the stage for further governmental oversight, regulation and control." 164 In the early 1800s, Parliament complained: "Were it not, indeed, that the locality of its wealth is at so remote a distance, the very existence of

158. Ibid., 112-13.

159. Burke 1909, 122.

160. Ibid., 123-24.

161. Ibid., 199, 283-84.

162. Ibid., 141-42, 143.

163. Dirks 2008, 201.

164. Dalrymple 2019, 314. 
such a body would be dangerous, not merely to the liberty of the subject, but to the stability of the state." 165 In 1858, more than 200 years after Westphalia, the English state took over direct rule in India. Layered sovereignty was stripped away, and it was no longer acceptable that company-states functioned as before. ${ }^{166}$

\section{Conclusion}

At 274 years, the EIC lasted longer than most states. This research note has examined the Company's sovereign awakening and its reckoning for modern state sovereignty. I have built on the literature on company-states to highlight that late modern England pared back layered sovereignty to take indivisible sovereignty more seriously. This process involved wrestling with a powerful company-state that located sovereignty within itself. By cataloguing the EIC's sovereign evolution and its state contests, the note contributes to fuller historicization of nonstate authority and the sovereign state system in two ways.

First, the research suggests that beyond building state capacity, 167 "war awakens sovereigns," by entangling entities in peacemaking. The EIC navigated complex sovereign claims by Asian powers and fended off European companies looking to take advantage, especially during the decline of the Mughal empire in the mid-1700s. Due to the communications lag with London, Company administrators were empowered with immense discretion to manage such diplomacy. Exposure to sovereign entanglements grew after the EIC conquered Bengal and contributed to awakening claims of self-possessed Company sovereignty. Elucidating the EIC's sovereign making reveals the meso dynamics of sovereignty construction through diplomatic practices ${ }^{168}$ by connecting micro managerial discussions with macro international structures of sovereignty.

Second, the Company's self-possessed sovereignty revealed problems with nonhierarchical early modern layered sovereignty that had been ignored. After the Company's assumption of the diwani, the English state introduced more hierarchical relations in layered sovereignty through the 1773 and 1784 acts and the rebukes in Hastings's impeachment. ${ }^{169}$ While eliminating the use of nonstate actors for sovereign functions was critical for institutionalizing nonintervention norms among late modern European states, ${ }^{170}$ the EIC's history underscores that states also confronted nonstate actors as sovereign rivals that could no longer be left unchecked. The research thus deepens our understanding of the co-evolutionary dynamics of

165. Bowen 2005, 16-17.

166. Phillips and Sharman 2020, 212.

167. Tilly 1985.

168. Biersteker and Weber 1996; Sending, Pouliot, and Neumann 2015; Wendt 1992.

169. Benton 2009; Dirks 2008.

170. Thomson 1994. 
state and corporate power undergirding transformations of sovereignty. ${ }^{171}$ The EIC's sovereign awakening was made possible by notions of layered sovereignty; this awakening, in turn, made possible the next iteration of sovereignty claims as more hierarchical. Ultimately, how we speak of and know about modern sovereignty in international relations ${ }^{172}$ is informed by changing international relations,,${ }^{173}$ including between states and nonstate actors.

\section{Supplementary Material}

Supplementary material for this research note is available at $<$ https://doi.org/10.1017/ S002081832200008X>.

\section{References}

\section{Primary}

India Office Records. Charters Granted to the East-India Company, from 1601; Also the Treaties and Grants, Made with, or Obtained, from the Princes and Powers in India, from the Year 1756 to 1772. IOR/A/2/3. British Library.

India Office Records. English East India Company Court of Directors Meeting Minutes, 1678-1795. IOR/ B/35 - IOR/B/120. British Library.

\section{Secondary}

Ashley, Richard. 1984. The Poverty of Neorealism. International Organization 38 (2):225-86.

Avant, Deborah. 2005. Market for Force: The Consequences of Privatizing Security. Cambridge University Press.

Bartelson, Jens. 1995. A Genealogy of Sovereignty. Cambridge University Press.

Bayly, C.A. 1988. The New Cambridge History of India: Indian Society and the Making of the British Empire. Cambridge University Press.

Benton, Lauren. 2009. A Search for Sovereignty: Law and Geography in European Empires, 1400-1900. Cambridge University Press.

Biersteker, Thomas, and Cynthia Weber, eds. 1996. State Sovereignty as Social Construct. Cambridge University Press.

Blachford, Kevin. 2020. Revisiting the Expansion Thesis: International Society and the Role of the Dutch East India Company as a Merchant Empire. European Journal of International Relations 26 (4):1230-48. Bodin, Jean. 1992. [1576]. On Sovereignty. Cambridge University Press.

Bogart, Dan. 2017. Policy Risk, Uncertainty, and Investment: Evidence from the English East India Company. Paper presented at the Society for Institutional and Organizational Economics annual meeting. <https://papers.sioe.org/paper/1906.html>.

Bolts, William. 1772. Considerations on India Affairs; Particularly Respecting the Present State of Bengal Dependencies, etc.

171. Cutler, Haufler, and Porter 1999; Mikler 2018; Strange 1996.

172. Bartelson 1995; Costa Lopez et al. 2018; Phillips and Sharman 2020.

173. Ashley 1984; de Carvalho 2021. 
Bose, Sugata. 2006. A Hundred Horizons: The Indian Ocean in the Age of Global Empire. Harvard University Press.

Bowen, H.V. 1991. Revenue and Reform: The Indian Problem in British Politics, 1757-1773. Cambridge University Press.

Bowen, H.V. 2005. The Business of Empire: The East India Company and Imperial Britain, 1756-1833. Cambridge University Press.

Branch, Jordan. 2012. "Colonial Reflection" and Territoriality: The Peripheral Origins of Sovereign Statehood. European Journal of International Relations 18 (2):277-97.

Burke, Edmund. 1909. Speeches on the Impeachment of Warren Hastings, 2nd ed. Bangabasi Press.

Chaudhuri, K.N. 1978. The Trading World of Asia and the English East India Company, 1600-1760. Cambridge University Press.

Costa Lopez, Julia. 2020. Political Authority in International Relations: Revisiting the Medieval Debate. International Organization 74 (2):222-52.

Costa Lopez, Julia, Benjamin de Carvalho, Andrew Latham, Ayse Zarakol, Jens Bartelson, and Minda Holm. 2018. Forum: In the Beginning There Was No Word (For It): Terms, Concepts, and Early Sovereignty. International Studies Review 20 (3):489-519.

Cutler, A. Claire, Virginia Haufler, and Tony Porter, eds. 1999. Private Authority and International Affairs. State University of New York Press.

Dalrymple, William. 2019. The Anarchy: The East India Company, Corporate Violence, and the Pillage of an Empire. Bloomsbury.

de Carvalho, Benjamin. 2021. Sovereignty in Historical International Relations: Trajectories, Challenges, and Implications. In Routledge Handbook of Historical International Relations, edited by de Carvalho, Costa Lopez, and Leira, 221-30. Routledge.

Dirks, Nicholas. 2008. The Scandal of Empire: India and the Creation of Imperial Britain. Harvard University Press.

Erikson, Emily. 2014. Between Monopoly and Free Trade: The English East India Company, 1600-1757. Princeton University Press.

Fuchs, Doris. 2007. Business Power in Global Governance. Lynne Rienner.

Glanville, Luke. 2013. The Myth of "Traditional” Sovereignty. International Studies Quarterly 57 (1): 79-90.

Hall, Rodney, and Thomas Biersteker, eds. 2002. The Emergence of Private Authority in Global Governance. Cambridge University Press.

Hobbes, Thomas. 1994 [1651]. Leviathan. Cambridge University Press.

Howell, Thomas Bayly, and Thomas Jones Howell. 1816. A Complete Collection of State Trials and Proceedings for High Treason and Other Crimes and Misdemeanors from the Earliest Period to the Year 1820. Vol. 10. T.C. Hansard.

Keene, Edward. 2002. Beyond the Anarchical Society: Grotius, Colonialism and Order in World Politics. Cambridge University Press.

Krasner, Stephen. 1993. Westphalia and All That. In Ideas and Foreign Policy: Beliefs, Institutions, and Political Change, edited by Goldstein and Keohane, 235-64. Cornell University Press.

Lawson, Philip. 1993. The East India Company: A History. Longman.

Mikler, John. 2018. The Political Power of Global Corporations. Polity.

Osiander, Andreas. 2001. Sovereignty, International Relations, and the Westphalian Myth. International Organization 55 (2):251-87.

Phillips, Andrew, and Jason Sharman. 2015. International Order in Diversity: War, Trade, and Rule in the Indian Ocean. Cambridge University Press.

Phillips, Andrew, and Jason Sharman. 2020. Outsourcing Empire: How Company-States Made the Modern World. Princeton University Press.

Robins, Nick. 2006. The Corporation that Changed the World: How the East India Company Shaped the Modern Multinational. Pluto Press.

Ruggie, John Gerard. 1993. Territoriality and Beyond: Problematizing Modernity in International Relations. International Organization 47 (1):139-74. 
Sending, Ole Jacob, Vincent Pouliot, and Iver B. Neumann, eds. 2015. Diplomacy and the Making of World Politics. Cambridge University Press.

Sharman, Jason. 2019. Power and Profit at Sea: The Rise of the West in the Making of the International System. International Security 43 (4):163-96.

Spruyt, Hendrik. 1994. The Sovereign State and its Competitors: An Analysis of Systems Change. Princeton University Press.

Srivastava, Swati. 2021. Algorithmic Governance and the International Politics of Big Tech. Perspectives on Politics. doi:10.1017/S1537592721003145.

Stern, Philip. 2008. "A Politie of Civil and Military Power": Political Thought and the Late SeventeenthCentury Foundations of the East India Company-State. Journal of British Studies 47 (2):253-83.

Stern, Philip. 2011. The Company-State: Corporate Sovereignty and the Early Modern Foundations of the British Empire in India. Oxford University Press.

Strange, Susan. 1996. The Retreat of the State: The Diffusion of Power in the World Economy. Cambridge University Press.

Thomson, Janice. 1994. Mercenaries, Pirates, and Sovereigns: State-Building and Extraterritorial Violence in Early Modern Europe. Princeton University Press.

Tilly, Charles. 1985. War Making and State Making as Organized Crime. In Bringing the State Back In, edited by Peter B. Evans, Dietrich Rueschemeyer, and Theda Skocpol, 169-91. Cambridge University Press.

Tilly, Charles. 1990. Coercion, Capital, and European States, AD 990-1990. Blackwell.

Vaughn, James. 2019. The Politics of Empire at the Accession of George III: The East India Company and the Crisis and Transformation of Britain's Imperial State. Yale University Press.

Wagner, Michael. 2018. The English Chartered Trading Companies, 1688-1763: Guns, Money and Lawyers. Routledge.

Watson, Adam. 1992. The Evolution of International Society: A Comparative Historical Analysis. Routledge.

Wendt, Alexander. 1992. Anarchy Is What States Make of It: The Social Construction of Power Politics. International Organization 46 (2):391-425.

Weststeijn, Arthur. 2014. The VOC as a Company-State: Debating Seventeeth-Century Dutch Colonial Expansion. Itinerario 38 (1):13-34.

Wood, Gordon. 1998 [1969]. The Creation of the American Republic, 1776-1787. University of North Carolina Press.

\section{Author}

Swati Srivastava is Assistant Professor of Political Science at Purdue University. She can be reached at srivas70@purdue.edu.

\section{Acknowledgments}

I thank Hendrik Spruyt, Steve Krasner, Ian Hurd, Sammy Barkin, Virginia Haufler, two anonymous reviewers, and the $I O$ editors for helpful comments on earlier versions of the manuscript.

\section{Key Words}

Sovereignty; empire; social construction; company-states; nonstate actors; corporate power; authority; archival methods

Date received: December 10, 2020; Date accepted: December 17, 2021 